\title{
Anopheles (Nyssorhynchus) atacamensis (Diptera: Culicidae), a new species from Northern Chile
}

\author{
Christian R González ${ }^{1,2} /{ }^{+}$, Maria Anice Mureb Sallum³ \\ 'Instituto de Entomología, Universidad Metropolitana de Ciencias de la Educación, Santiago, Chile 2Instituto de Salud Pública, Santiago, Chile \\ ${ }^{3}$ Departamento de Epidemiologia, Faculdade de Saúde Pública, Universidade de São Paulo, São Paulo, SP, Brasil
}

Anopheles (Nyssorhynchus) atacamensis, a new species in the subgenus Nyssorhynchus, is described and validated using morphological characters of the male and female adult, male genitalia and immature stages. Molecular characterization employing sequences of the ITS2 rDNA and COI mtDNA are provided. The new taxon is compared with Anopheles (Nyssorhynchus) pictipennis (Philippi) from central Chile based on morphological features of the adults, male genitalia and larva. Illustrations of the diagnostic characteristics of the male genitalia, fourth-instar larva and pupa are provided.

Key words: new species - Nyssorhynchus - An. pictipennis - COI - ITS2 - III Región de Atacama - Chile

Anopheles (Nyssorhynchus) atacamensis, new species, is the third species of the genus Anopheles Meigen reported in Chile and the second of the subgenus Nyssorhynchus Blanchard. This new species was identified as Anopheles (Nyssorhynchus) pictipennis (Philippi) in Northern Chile (Rueda et al. 2008). However, morphological comparisons of characteristics of the male and female adult, male genitalia, fourth-instar larva and pupa between the neotype and specimens of An. pictipennis from III Región de Atacama, Northern Chile, revealed that there are two species under the name An. pictipennis: An. pictipennis s.s. and a new species. The major objectives of this study are to describe and validate the new species from the III Región de Atacama, Chile. Morphological comparisons between An. atacamensis n. sp. and An. pictipennis from the type locality are discussed. Illustrations of diagnostic characteristics of the adults, male genitalia, fourth-instar larva and pupa are provided.

\section{MATERIALS AND METHODS}

Mosquitoes were collected in the III Región de Atacama, Chile, as follows: Provincia de Huasco, Carrizalillo (29 $06^{\prime}$ 'S $71^{\circ} 24^{\prime} \mathrm{W}$ ), Quebrada Honda, El Sarco (28 $\left.8^{\circ} 13^{\prime} \mathrm{S} 71^{\circ} 07^{\prime} \mathrm{W}\right)$ and Provincia de Copiapó, Perales $\left(27^{\circ} 52^{\prime} \mathrm{S} 70^{\circ} 54^{\prime} \mathrm{W}\right)$, Sector Totoral $\left(27^{\circ} 53^{\prime} \mathrm{S} 70^{\circ} 56^{\prime} \mathrm{W}\right)$, Las Salinas $\left(27^{\circ} 18^{\prime} \mathrm{S} 70^{\circ} 55^{\prime} \mathrm{W}\right)$. Larvae were taken from small ground pools. The water was fresh, temperature varying from $14-17^{\circ} \mathrm{C}$, deeply shaded, in oasis localities

Financial support: FAPESP (05/53973-0 to MAMS), CNPq (PP 300351/2008-9 to MAMS), Ministerio de Salud of Chile, Instituto de Salud Pública de Chile, Dirección de Investigación UMCE (projects FIBAS 09/06, FIBAS 05/09)

+ Corresponding author: christian.gonzalez@umce.cl

Received 22 July 2009

Accepted 19 October 2009 in the Atacama Desert. Immature stages were taken from the habitat with a pipette. Some larvae were preserved in $80 \%$ ethanol, whereas others were pooled and transported to the laboratory and reared to obtain adults. The morphological terminology for the adults and immature stages follows Harbach and Knight (1980), for the wing veins we adopted Belkin (1962) and Wilkerson and Peyton (1990) for the wing pale and dark spots. Fourth-instar larvae and pupae were cleared in $10 \% \mathrm{KOH}$ and mounted on microscope slides. Male genitalia were removed from the adult and macerated in a solution of $20 \% \mathrm{KOH}$, stained with acid fuchsin, dehydrated in ETOH from $70-100 \%$ and subsequently dissected and mounted on a microscope slide in Canada balsam. Images of the male genitalia, larvae and pupae were recorded with a microscope using the Axiovision software version 3.0.6 SP4 (Carl Zeiss MicroImaging GmbH, Thornwood, NY).

DNA was extracted from two mosquito specimens following the insect DNA extraction protocol provided by the QIAgen DNeasy ${ }^{\circledR}$ Blood and Tissue Kit (QIAgen Ltd, Crawley, UK). Both specimens were collected in Provincia de Huasco, Quebrada Honda, El Sarco, C. Araya coll, in 25th May 2006.

ITS2 ribosomal DNA - Amplification of the ITS2 region was carried out using the 5.8SF (5'-ATC ACT CGG CTC GTG GAT CG - 3') and 28SR (5'-ATG CTT AAA TTT AGG GGG TAG TC - 3') primers (Djadid et al. 2007). PCR products were amplified in $25 \mu \mathrm{L}$ reaction mix containing: $1 \mu \mathrm{L}$ of DNA of the first elution; $10 \mathrm{mM}$ Tris- $\mathrm{HCl}, \mathrm{pH} 8.3 ; 50 \mathrm{mM} \mathrm{KCl} ; 1.5 \mathrm{mM} \mathrm{MgCl} 2 ; 2.5 \mu \mathrm{L}$ DMSO; 5 pmol of each primer; $200 \mu \mathrm{M}$ each dNTPs and 2.5 U New England Biolabs ${ }^{\circledR}$ Taq polymerase. PCR protocol consisted of a $2-\mathrm{min}$ denaturation at $94^{\circ} \mathrm{C}$, 34 cycles at $94^{\circ} \mathrm{C}, 57^{\circ} \mathrm{C}$ and $72^{\circ} \mathrm{C}$ for $30 \mathrm{sec}$ each, followed by a 10 -min extension at $72^{\circ} \mathrm{C}$. ITS2 PCR amplicons obtained from two individuals were purified using PEG precipitation (20\% polyethylene glycol 8000/2.5 M $\mathrm{NaCl}$ ) and cloned into pGem-T Easy Vector (Promega, Madison, WI, USA). Three to five positive clones were sequenced per individual specimen. 
COI mtDNA - COI fragments of $\sim 500$ base pairs (bp) were amplified using the primers C1-J-1718 (5'- GGA GGA TTT GGA AAT TGA TTA GTT CC-3') and C1N-2191 (5'-CCC GGT AAA ATT AAA ATA TAA ACT TC -3') (Simon et al. 1994). Each PCR reaction contained $1 \mu \mathrm{L}$ DNA; $10 \mathrm{mM}$ Tris-HCl, $\mathrm{pH} 8.3 ; 50 \mathrm{mM} \mathrm{KCl} ; 1.5$ $\mathrm{mM} \mathrm{MgCl} 2,2.5 \mu \mathrm{L}$ DMSO; 5 pmol of each primer; 200 $\mu \mathrm{M}$ each dNTPs; and 2.5 U New England Biolabs ${ }^{\circledR}$ Taq polymerase and the remaining volume of ultrapure $\mathrm{H}_{2} \mathrm{O}$ up to $25 \mu \mathrm{L}$. PCR amplification protocol consisted of a 3 -min denaturation at $94^{\circ} \mathrm{C}$ and 35 cycles at $94^{\circ} \mathrm{C}, 55^{\circ} \mathrm{C}$ and $72^{\circ} \mathrm{C}$ for $1 \mathrm{~min}$ each, followed by a 7 -min extension at $72^{\circ} \mathrm{C}$. Sequencing reactions were carried out in both directions using ABI Big Dye Terminator Kit v.3.1 (PE Applied Biosystems, Warrington, England) with the same primers used for PCR. Sequencing reactions were purified in Sephadex G50 ${ }^{\circledR}$ columns (GE Healthcare). Sequences were analyzed on an ABI Prism 3100 - Avant Genetic Analyzer (Applied Biosystems, Foster City, CA, USA) and edited using Sequencher ${ }^{\circledR}$ for Windows version 4.9 (Gene Codes Corporation, Ann Arbor, USA).

Template DNA from this study is retained at $-70^{\circ} \mathrm{C}$ in the Faculdade de Saúde Pública (FSP-USP) for future reference. DNA vouchers consist of wings and legs mounted on microscope slides (E-12992) and head, thorax, one wing and legs pinned and one wing mounted on microscope slide (E-12993). Sequences were aligned and optimized manually in MacClade version 4.8 (Maddison $\&$ Maddison 2000). Sequence similarities of the ITS2 and $\mathrm{COI}$ sequences generated in this study with those previously available in GenBank was assessed using the Basic Local Alignment Tool search (http:/www.ncbi. nlm.nih.gov/BLAST) and documented using PAUP* 4.0 software (Swofford 2003).

\section{RESULTS}

\section{An. (Nyssorhynchus) atacamensis González and Sallum, n. sp.}

An. pictipennis of Rueda et al. (2008): 448.

Etymology - The name, atacamensis, is derived from the name of the geographical locality where the specimens were first collected, the Atacama Region of Northern Chile.

Diagnosis - In the adult stage, An. atacamensis can be recognized by a combination of characters as follows: dark grayish pruinosity, central portion of the head bare. Scutal integumen grayish, scutal scales large, with a pair of broad, subdorsal stripes extending posteriorly from anterior scutal angle to scutellum. Acrostichal area with two lines of white spatulate scales, reaching anterior margin of scutellum, two lines of white spatulate scales extending posteriorly along dorsocentral area scales, white spatulate scales scattered on posterior portion of dorsocentral area, scutal fossa with few scattered, white spatulate scales, becoming a line of white spatulate scales on prealar, supraalar areas. Hindtarsomere five mostly white-scaled with dark ring at apex. Abdominal integument dark brown, terga II-VII with whitish scales medially, without caudolateral scale-tufts (Table I).

Female - Integument dark with grayish pruinosity.
Head: interocular space wide with 6-10 long, pale proclinate setae with golden sheen, intermixed with white scales along ocular margin, central portion bare; vertex with erect scales, white scales on dorsal portion, dark scales laterally, intermixed with few sparse pale scales on anterior margin; occiput and dorsal portion of postgena with numerous dark erect scales. Clypeus dark brown, bare, somewhat square in outline, with small anterior and posterior lateral lobes. Pedicel of antenna with small broad white scales dorsally; flagellomere 1 basally narrow to broad, inner, ventral and lateral surfaces covered with white spatulate scales, dorsal surface bare, flagellomere 2 with white spatulate scales on ventral surface, scaling extending to lateral and inner surfaces, dorsal surface bare, flagellomeres 3,4 and 5 with white, spatulate scales on lateral surface, flagellomeres 6-13 without scales. Scales of maxillary palpus elongate, spatulate, mostly dark brown, palpomere 2 with semierect to erect scales at basal 0.5 , distal 0.5 of palpomere 2, palpomeres 3-5 with decumbent scales, narrow patches of white scales at apex of palpomeres 2 and 3 , palpomere 4 mostly dark-scaled, with few pale scales at apex of dorsal surface at edge of inner surface, palpomere 5 dark-scaled at basal 0.5 , white-scaled at distal 0.5 , base of palpomere 2 with one long dark seta laterally, maxillary palpus length $2.3-2.8 \mathrm{~mm}($ mean $=2.53 ; \mathrm{n}=3)$. Proboscis dark-scaled with long setae at base of ventral surface, proboscis length 2.3-2.7 $\mathrm{mm}$ (mean $=2.51 ; \mathrm{n}=$ 3 ), ratio of proboscis and maxillary palpus lengths 0.96 $1.01($ mean $=0.99 ; \mathrm{n}=3)$.

Thorax: scutal integument grayish pruinose with dark, nonpruinose, longitudinal stripes as follow: a narrow, median stripe along acrostichal area extending from anterior promontory to posterior end of scutum and a pair of broad, subdorsal stripes extending posteriorly from anterior scutal angle to scutellum. Acrostichal area with two lines of white spatulate scales, extending posteriorly, reaching anterior margin of scutellum, acrostichal setae strong, dark brown with golden reflections, two lines of white spatulate scales extending posteriorly along dorsocentral scales, intermixed with dark, long setae with golden reflection, white spatulate scales scattered on posterior portion of dorsocentral area, becoming a line of scales at lateral portions of prescutellar area, scutal fossa with few scattered, white spatulate scales, scales more concentrated on prescutal suture, becoming a line of white spatulate scales on prealar, supraalar areas; lateral borders of scutum covered with line of white spatulate scales reaching posterior end of paratergite; scutal setae brown with golden reflections. Scutellum pale dusted with long dark setae along posterior margin, with white, spatulate scales anterior to setae, integument of median scutellar lobe brown. Antepronotum with a patch of long dark scales at dorsomedial portion, with scattered dark long setae. Thoracic integument grayish. Upper proepisternum with 4-6 setae, with few white scales; prespiracular area without setae, with 2,3 white spatulate scales; prealar area with setae intermixed with white spatulate scales; upper mesokatepisternum with dark brown setae, with a patch of white spatulate scale, posterior border of mesokatepisternum with a patch of 
TABLE I

Morphological differences between Anopheles pictipennis and Anopheles atacamensis

\begin{tabular}{|c|c|c|c|}
\hline & An. pictipennis & An. atacamensis $(\mathrm{F} 1)$ & An. atacamensis $(\mathrm{F} 2)$ \\
\hline Flagellomere 1 & without scales on dorsal surface & without scales on dorsal surface & $\begin{array}{l}\text { with narrow scales on dorsal } \\
\text { surface }\end{array}$ \\
\hline Clypeus & oval & square & rounded \\
\hline $\begin{array}{l}\text { Proboscis, apex at mar- } \\
\text { gin of labella }\end{array}$ & with pale scales & with pale scales & with dark scales \\
\hline Scutum & $\begin{array}{l}\text { grayish; scales on posterior } \\
\text { region of the acrostichal and } \\
\text { dorsocentral areas spatulate; } \\
\text { prescutellar area with lateral } \\
\text { line of white scales }\end{array}$ & $\begin{array}{l}\text { grayish; scales on posterior region } \\
\text { of the acrostichal and dorsocentral } \\
\text { areas spatulate; prescutellar area } \\
\text { with lateral line of white scales }\end{array}$ & $\begin{array}{l}\text { blackish; scales on posterior } \\
\text { region of the acrostichal and } \\
\text { dorsocentral areas narrow } \\
\text { spatulate; prescutellar area } \\
\text { with sparse, white scales }\end{array}$ \\
\hline Scutellum & $\begin{array}{c}\text { pale dusted with white, spatu- } \\
\text { late scales on median lobe, long, } \\
\text { narrow, truncate white scales on } \\
\text { lateral lobes }\end{array}$ & $\begin{array}{l}\text { with scales on lateral lobes and } \\
\text { laterally on medial lobe }\end{array}$ & $\begin{array}{l}\text { with scales posteriorly on } \\
\text { lateral and medial lobes }\end{array}$ \\
\hline Hindtarsomere 2 & $\begin{array}{l}\text { dark-scaled on basal } 0.7 \text {, white- } \\
\text { scaled on apical } 0.3\end{array}$ & $\begin{array}{l}\text { dark-scaled on basal } 0.8 \text {, white- } \\
\text { scaled on apical } 0.2\end{array}$ & dark \\
\hline Hindtarsomere 3 & entirely white & entirely white & $\begin{array}{l}\text { dark-scaled at basal } 0.2 \text {, } \\
\text { white at apical } 0.8\end{array}$ \\
\hline Hindtarsomere 5 & entirely white & white, with apical dark ring & white, with apical dark ring \\
\hline $\begin{array}{l}\text { Scales on dorsal surface } \\
\text { of } R_{4+5}\end{array}$ & $\begin{array}{l}\text { mostly pale-scaled, a small } \\
\text { postbasal dark patch, and a } \\
\text { small preapical dark patch }\end{array}$ & $\begin{array}{l}\text { proximal end with a small white } \\
\text { patch, a postbasal dark patch, re- } \\
\text { maining of vein white-scaled }\end{array}$ & $\begin{array}{c}\text { a dark patch on proximal } \\
0.2 \text {, white patch at middle, a } \\
\text { dark patch on preapical por- } \\
\text { tion, and a small white patch } \\
\text { at apex }\end{array}$ \\
\hline $\begin{array}{l}\text { Scales on dorsal surface } \\
\text { of } \mathrm{Cu}\end{array}$ & $\begin{array}{c}\text { mostly pale-scaled, with dark } \\
\text { scales on proximal } 0.5 \text { of distal } \\
0.5 \text {, pale-scaled on distal } 0.5, \\
\text { bifurcation of } \mathrm{Cu}_{1} \text { and } \mathrm{Cu}_{2} \\
\text { pale-scaled }\end{array}$ & $\begin{array}{c}\text { with pale scales on proximal } 0.5 \text {, } \\
\text { distal } 0.4 \text { dark scaled, dark-scales } \\
\text { not reaching bifurcation of } \mathrm{Cu}_{1} \text { and } \\
\mathrm{Cu} \text { which is pale-scaled }\end{array}$ & $\begin{array}{l}\text { with pale scales on proximal } \\
0.5 \text {, distal } 0.5 \text { dark-scales, } \\
\text { reaching bifurcation of } \mathrm{Cu}_{1} \\
\text { and } \mathrm{Cu}_{2}, \text { bifurcation of } \mathrm{Cu}_{1} \\
\text { and } \mathrm{Cu}_{2} \text { pale-scaled }\end{array}$ \\
\hline $\begin{array}{l}\text { Scales on dorsal surface } \\
\text { of } \mathrm{Cu}_{1}\end{array}$ & $\begin{array}{l}\text { proximal } 0.5 \text { pale-scaled, inter- } \\
\text { rupted by two submedian dark } \\
\text { spots, distal } 0.5 \text { dark-scaled, } \\
\text { apex pale }\end{array}$ & $\begin{array}{l}\text { proximal } 0.5 \text { white-scaled, with a } \\
\text { dark and white patches at middle, } \\
\text { dark-scaled on distal } 0.3 \text {, apex with } \\
\text { a small white patch }\end{array}$ & $\begin{array}{l}\text { proximal } 0.5 \text { dark with pale } \\
\text { scales at proximal end, a } \\
\text { small submedian pale patch, } \\
\text { dark-scaled distally with a } \\
\text { few pale scales at distal apex }\end{array}$ \\
\hline $\begin{array}{l}\text { Scales on dorsal surface } \\
\text { of } \mathrm{Cu}_{2}\end{array}$ & $\begin{array}{l}\text { proximal } 0.5 \text { pale-scaled, distal } \\
0.5 \text { dark-scaled, apex pale }\end{array}$ & $\begin{array}{l}\text { mostly white-scaled, a dark preapi- } \\
\text { cal patch, apex pale }\end{array}$ & $\begin{array}{l}\text { pale-scaled, distal } 0.5 \text { dark- } \\
\text { scaled, apex pale }\end{array}$ \\
\hline
\end{tabular}

F1, F2: morphological forms of An. atacamensis from distinct localities in the III Región de Atacama, Northern Chile.

white scales at level of upper margin of mesomeron; upper mesepimeron with 5-8 setae, a patch of white scales anterior to setae. Legs. Coxa and trochanters grayish; forecoxa with white scale-patches on dorsal and ventral margins of anterior surface; midcoxa with white scales on dorsal anterior and posterior surfaces and on ventral posterior surface; hindcoxa with white scales on dorsal and ventral margins of lateral surface and a patch on ventral margin of posterior surface. Forefemur with white and dark scales, scales at base forming pale and dark rings, anterior surface mostly dark with scattered pale scales along margins extending most of the length of the segment, apex usually with white scales; midfemur with pale and dark scales at base forming pale and dark bands, anterior surface dark-scaled, with white scales at apex, posterior surface mostly pale-scaled, dark-scaled at basal 0.3 , lateral surface mostly dark with ovoid, white patch extending to anterior surface; hindfemur with pale and 
dark scales at base forming one pale and one dark band, anterior surface dark with narrow line of white scales extending from a large, elongate, subapical white patch, pale scales at apex; posterior surface white-scaled, dark at subapical portion, with white scales at apex. Tibiae with pale and dark golden-brown scales forming longitudinal pale stripes, mid and hindtibiae with longitudinal line of white scales interrupted at subapical portion of both ends, with patches of white scales at apex; tarsi with scales varying from white to golden to black; fore, mid and hindtarsomeres 1 mostly pale-scaled, with dark ring at base, dark at subapical portion, with broad apical band of white scales; foretarsomeres 2,3 dark-scaled, with apical ring of variable length of white scales, foretarsomeres 4,5 dark-scaled; midtarsomere 2 dark-scaled, with white ring at apex, midtarsomeres 3,4 and 5 darkscaled; hindtarsomere 2 dark-scaled at basal 0.8, whitescaled at apical 0.2 , hindtarsomeres 3,4 entirely whitescaled, hindtarsomere 5 mostly white-scaled with dark ring at apex. Wing. Length 4.02-4.85 $\mathrm{mm}($ mean $=4.29$; $\mathrm{n}=6$ wings of 3 specimens). Dark scales brown, pale wing scales white on most proximal pale spots and posterior veins, pale yellowish on subcostal pale, preapical pale and apical pale spots. Costa with prehumeral dark, presector dark, sector dark, preapical dark and apical dark spots, basal and prehumeral pale spots fused, humeral pale, accessory sector pale, subcostal pale, preapical pale and apical pale spots; vein Rs dark-scaled; $\mathrm{R}_{2+3}$ dark-scaled at base and apex; $\mathrm{R}_{4+5}$ with one or two pale scales at proximal end, dark-scaled on proximal 0.2 , paled-scaled on distal 0.8 . Vein M mostly dark-scaled, with pale spot at base and medial portion, with a pale spot at basal 0.5 , dark-scaled distally, split of veins $\mathrm{M}_{1+2}$ and $\mathrm{M}_{3+4}$ pale-scaled. Vein $\mathrm{Cu}$ pale-scaled on proximal 0.6 , dark-scaled distally; vein 1A dark-scaled with small pale spots at proximal and distal ends and along middle. Pale fringe spots at distal end of each vein. Halter. Scabellum and pedicel with pale brown integument, capitellum dark brown-scaled.

Abdomen: integument dark brown, terga II-VII with dense covering of whitish scales medially, without caudolateral scale-tufts, tergum VIII covered with scales, terga with long pale brown and yellowish setae. Sternum I bare, sterna II-V with longitudinal patches of pale scales lateral of longitudinal midline, sterna VI-VII pale-scaled medially, sternum VIII mostly pale-scaled.

Male (Figs 1, 2) - Similar to female except for the following sexual differences: ratio of maxillary palpus and proboscis length $0.90-1.12($ mean $=1.01 ; n=3)$, mostly dark-scaled, with a white band at apex of palpomere 2, palpomere 3 dark-scaled with a broad white band at subapical portion extending laterally and ventrally and wide white band at apex; palpomere 4 dark with white band at apex; palpomere 5 dark basally, white-scaled on apical 0.5 ; palpomere 3 with tufts of long, strong, dark setae at apex of ventral surface, palpomeres 4 and 5 some-

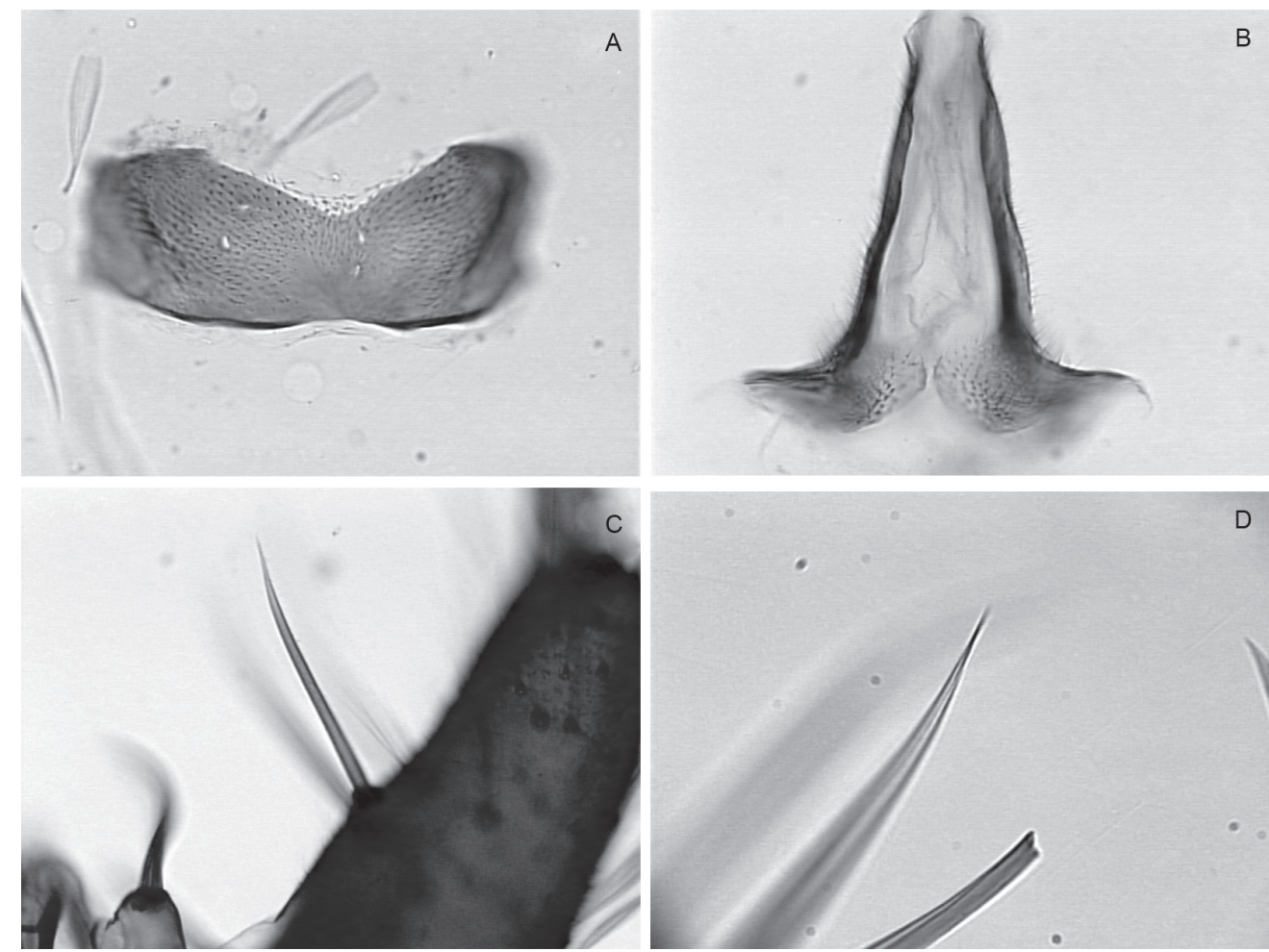

Fig. 1: Anopheles (Nyssorhynchus) atacamensis, male genitalia. A: segment IX; B: proctiger; C: dorsal accessory seta; D: apex of ventral accessory seta. 

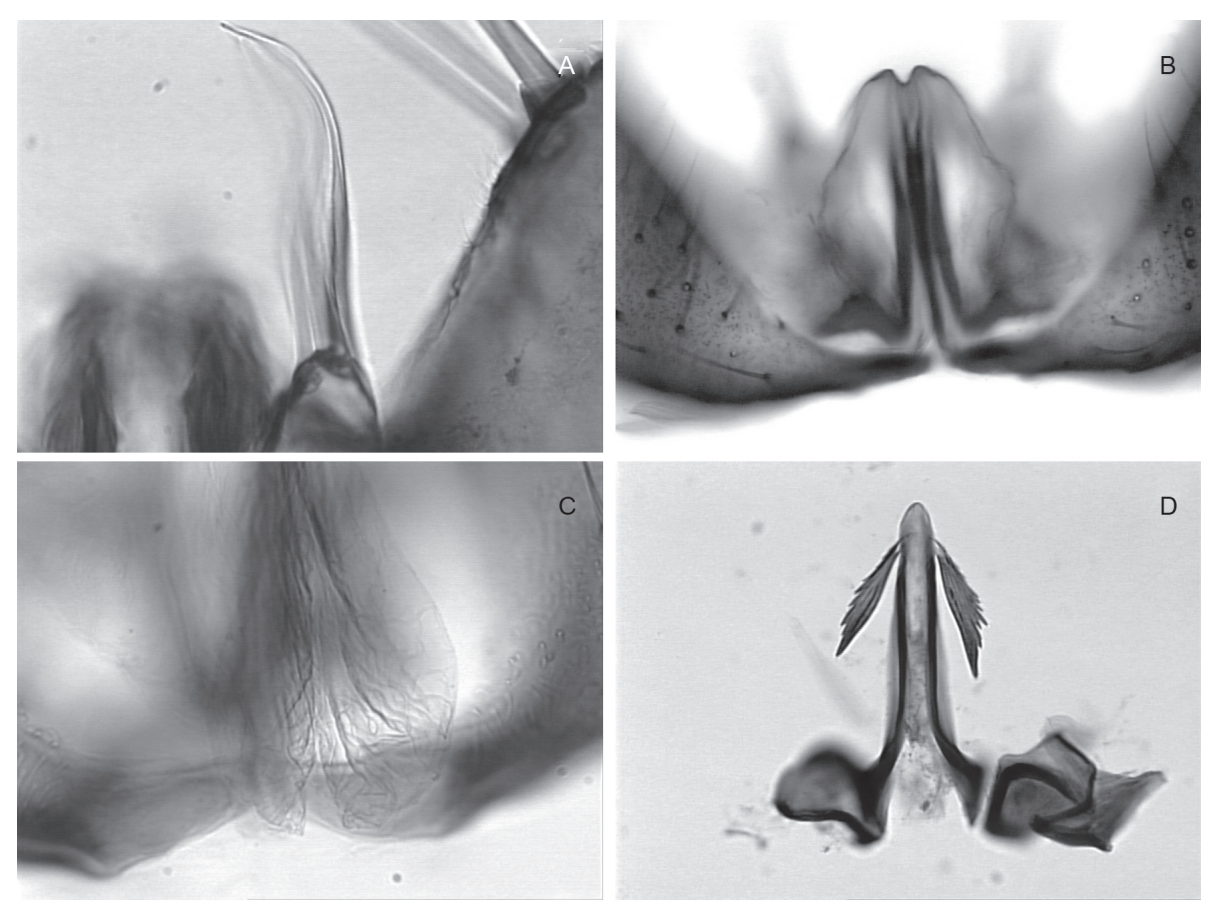

D

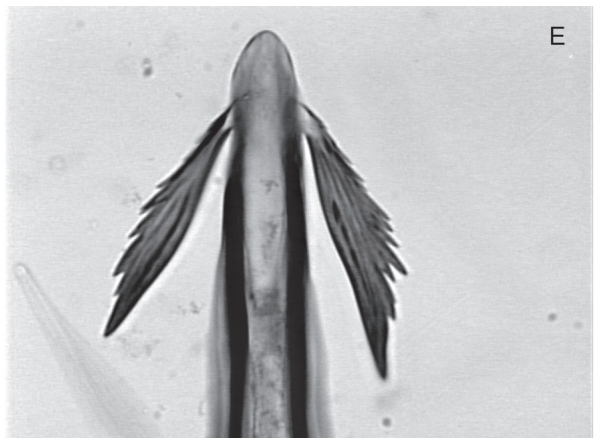

Fig. 2: Anopheles (Nyssorhynchus) atacamensis, male genitalia. A: dorsal claspette; B: ventral claspette; C: ventral lobe of ventral claspette; D: aedeagus; E: detail of apex of aedeagus.

what fused, enlarged, palpomere 4 with long, dark setae extending from base to apex of dorsal and ventral margins of inner surface. Genitalia. Tergum VIII with few short setae distally, with long, spatulate scales scattered on segment, more numerous on basal 0.5; sternum VIII with scattered short to long setae and few sparse, slender, spatulate scales, distal margin convex. Segment IX spiculose (Fig. 1A); tergum poorly developed, membranous, developed laterally, sternum well developed, subrectangular, distal margin superficially emarginated, with shallow depression at middle, apodeme absent. Tergum X, paraproct and lateral portions of cerci spiculate, spicules extending to posterior end of proctiger (Fig. 1B). Gonocoxite cylindrical, mesally straight, dorsolateral surface with long, spatulate scales from base to apex, tergal surface with short to long setae, with 4,6 $(n=4)$ tergomesal setae; tergomesal surface with two accessory setae (Fig. $1 \mathrm{C}, \mathrm{D})$ arising from two well-developed prominent tubercles, dorsal seta arising 0.45-0.63 (mean $=0.56 ; \mathrm{n}=$ 4) from base of gonocoxite, ventral seta arising 0.5-0.69 $($ mean $=0.61 ; \mathrm{n}=4)$ from base of gonocoxite, accessory setae cylindrical, sharply pointed at apex, straight or slightly curved apically, dorsal and ventral setae similar in length and development; internal seta arises from a small tubercle, $0.58-0.69$ (mean $=0.64 ; n=4)$ from base of gonocoxite; parabasal setae strong, short, hooked at apex, inserted in a short tubercle. Gonostylus 0.82-0.86 (mean $=0.92 ; n=4)$ length of gonocoxite, curved mesally along entire length, slightly broad at base ending in a somewhat truncate apex, gonostylar claw short, strong arising from apex of ventral surface; ventromesal surface with short, slender setae. Dorsal claspette (Fig. 2A) with two large setae curved at apical 0.5 and 1 smaller, more slender, straight seta, pedicel somewhat subrectangular, with rounded base and one protuberance at base of ventral surface. Ventral claspette (in ventral view) (Fig. 2B) entirely bare, somewhat rounded, tapering to apex, apex narrow, ventrally with numerous fine laterally directed striations, median sulcus with distal opening straight, long, strongly sclerotized with more sclerotized area approximately at mid-length, claspette with two well-developed lobes well expanded ventrally (Fig. 
2C), continuing to basal lobules which are expanded ventrally, semicircular along margin; refringent structure absent. Aedeagus (Fig. 2D, E) with apex longer than wide, apex curved dorsally, strongly sclerotized laterally, weakly sclerotized at apex and on lateral margins; ventromesal subtriangular projections strongly sclerotized, meeting on midline forming a subapical collar, with a pair of well-developed subapical leaflets; leaflets straight, strongly sclerotized, dorsolaterally projecting, inner margin straight, smooth, dorsal, ventral and lateral surfaces strongly serrated, ending in a narrow point, leaflets arising subapically from a membranous lateral area at apex of aedeagus.

Fourth-instar larva (Fig. 3) - Head: with dark pigmented areas, posteriorly on dorsal apodeme, posteriorly on ecdysial line and lateralia, posteriorly on labiogula. Collar well developed, moderately large, strongly sclerotized. Dorsomentum well developed, strongly sclerotized. Ventromentum well developed, strongly sclerotized with three lateral teeth. Hypostomal suture short, not extending to tentorial pit. Median labral plate moderately developed, with small lateral lobe bearing seta 1-C. Seta 2-C widely spaced, single with few moderately developed spicules distally, 3-C shorter than 2-C, spiculate, distance between 2-C equal distance 2-C to $3-\mathrm{C}$, clypeal index 1.0, 4-C strongly developed, similar to $3-\mathrm{C}$, single, simple, extending beyond base of 2-C. Setae 5-7-C plumose, long, 5-C with 12 branches, extending well beyond base of 2-C, 6-C with 13 branches, extending to base of 3-C, 7-C with 15 short branches, inserted in line with insertions of 5,6-C, 8-C with two or three branches, 9-C with three branches, 10-C triple, 11-C plumose, number of branches not counted, 12-C with four or five branches, 13-C with three branches, 14-C min, branched, 15-C with two or three branches, mesad of hypostomal suture. Antenna. Flagellum strongly aciculate, with strong spicules on dorsal, ventral and mesal surfaces, seta 1-A longer than width of flagellum at the point of insertion, moderately large, arising from dorsomesal surface, about 0.3 from base.

Thorax: setae 9-12-P,M,T inserted on large common tubercle, with a large, moderately pigmented, lateral spine. Prothorax. Seta 1-P fanlike (Fig. 3A) with thin branches, not inserted on common tubercle with 2-P (Fig. 3B), 2-P plumose with nine branches inserted on large tubercle closer to 3-P than 1-P, 3-P single, simple, short, inserted on tubercle with 2-P, 4-P plumose with 25 branches, 5-P plumose, 6-P long, single, simple, 7-P plumose, 8-P plumose with nine or 10 branches inserted on a moderately large tubercle lateral of setae 9-12-P, 14-P with three branches, moderately long. Mesothorax. Seta 1-M plumose, moderately long, inserted on large tubercle, 2-M single, simple or forked, 3,5-M single, simple, 4-M with three branches, shorter than 3-M, 6-M with three branches, moderately long, 7-M with four branches similar to 4-M, 8-M plumose, 14-M pectinate, small with six branches arising near ventral midline. Metathorax. Seta 1,2-T single and simple, short, 1-T similar to 2-T, 3-T fanlike with six thin branches (Fig. 3B), 4-T small with three or four branches, 13-T double.

Abdomen: median tergal plates present, moderately large, strongly sclerotized, arising on anterior margin of segments I-VIII, accessory median and submedian tergal plates arising posterior of median tergal plates, subspherical, small. Seta 1-I fanlike with seven branches (Fig. 3C), 1-II-VII palmate with serrated moderately broad, lanceolate branches (Fig. 3D, E). Seta 2-I small, bifid or triple, 2-II moderately large with six branches, 2-III
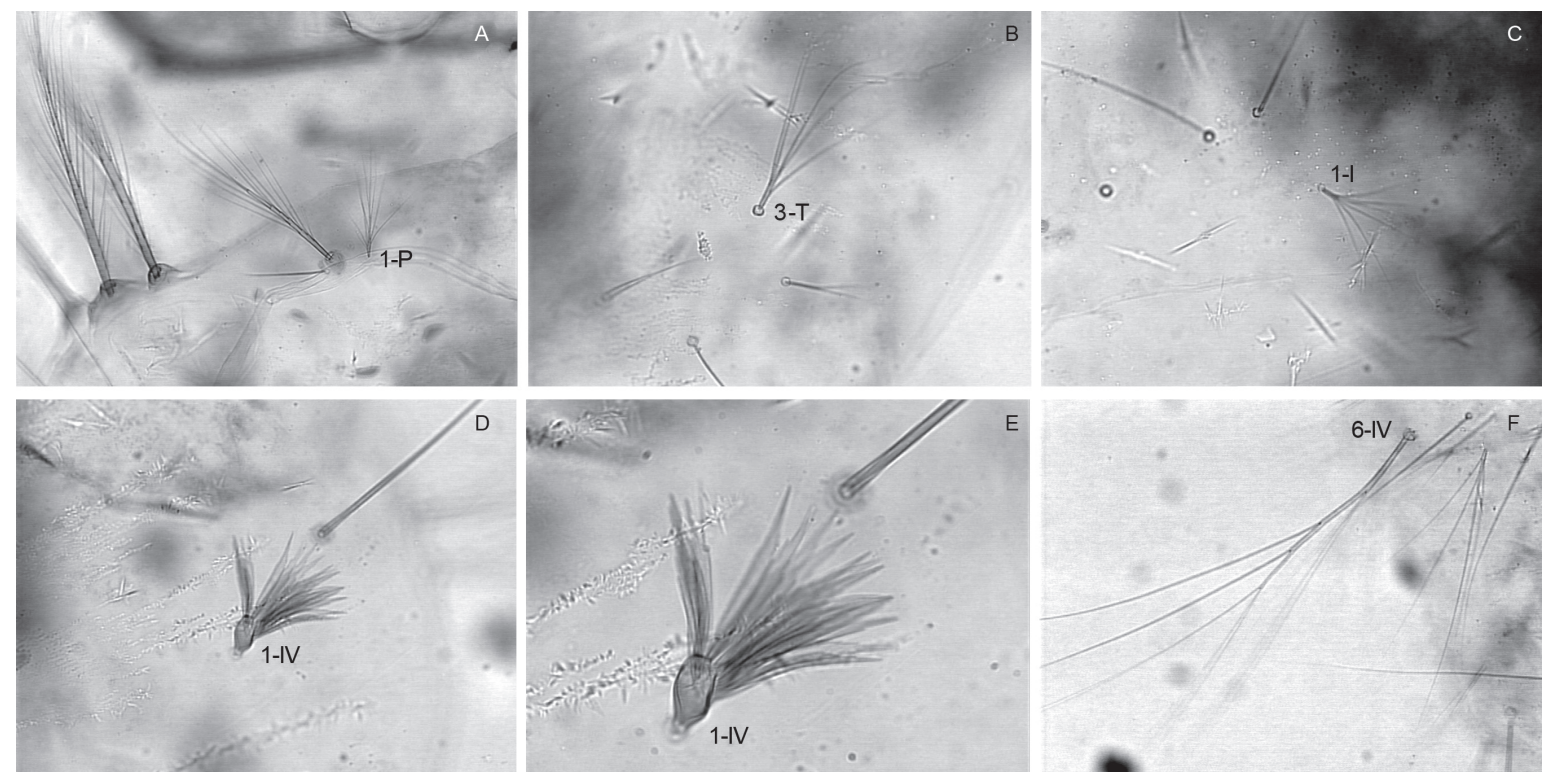

Fig. 3: Anopheles (Nyssorhynchus) atacamensis, fourth-instar larvae. A: seta 1-P; B: seta 3-T; C: seta 1-I; D: seta 1-IV; E: detail of seta 1-IV; F: seta 6-IV. 
large, triple, 2-IV single, simple, 2-V double or triple, 2-VI triple, 2-VII triple. Seta 3-I single, 3-II single, 3-III single, 3-IV single, 3-V single, 3-VI single, 3-VII triple. Seta 6-I-III plumose, inserted on distinct tubercle, 6-IVVI long, branched (Fig. 3F), 6-VII branched. Seta 7-I-II plumose, long, inserted on tubercle with 6-I,II, 7-III with four branches, 7-IV triple, 7-V triple, 7-VI triple, 7-VII with five branches. Seta 8-III double, 8-IV double, 8-V double, 8-VI double, 8-VII with four or five branches. Seta 9-I with five branches, 9-II with six branches, 9-III with six branches, 9-IV with four branches, 9-V with three branches, 9-VI triple, 9-VII with five branches. Seta 10-I single, 10-II single, 10-III single, 10-IV single, 10-V single, 10-VI single, 10-VII with four branches. Seta 11-I triple, 11-II single, 11-III single, 11-IV single, 11-V single, 11-VI double, 11-VII single. Seta 12-I with three branches, 12-II single, 12-III single, 12-IV double, 12-V single, 12VI single, 12-VII single. Seta 13-I with three branches, 13II with four branches, 13-III with three branches, 13-IV with five branches, 13-V with three branches, 13-VI with five branches, 13-VII with four branches. Segment VIII. Seta 1-VIII triple, 2-VIII with five branches, 3-VIII with five branches, 4-VIII single, 5-VIII with five branches. Spiracular lobe. Pecten with seven long teeth intermixed with 12 short teeth, teeth length variable, teeth usually curved dorsally with serrations on base. Median plate strongly pigmented without lateral arms, anterior median process of median plate strongly sclerotized and short. Seta 1-S strongly developed with four branches, inserted on caudal surface of posterolateral spiracular lobe near posterodorsal margin of pecten, 6-S with four branches, 7-S single, 8-S with five branches, 9-S double, 10-13-S single, small. Segment X. Saddle incomplete, 1-X single, well developed, long, inserted outside the saddle, 2-X strongly plumose, seta $4-\mathrm{X}$ with 8.5 pairs of long, strongly developed, plumose setae.

Pupa (Fig. 4): cephalothorax. Seta 2-C double. Seta 3-C triple. Seta 8-C single, well developed, heavily pigmented, inserted at level of base of trumpet. Seta 9-C with 2-5 branches, small, inserted posterior to base of trumpet. Trumpet. Gradually broadening from base to apex, angusticorn. Meatal cleft large. Metanotum. Seta $10,11-\mathrm{C}$ subequal, $12-\mathrm{C}$ longer. Seta $10-\mathrm{C}$ single to triple. Seta $11-\mathrm{C}$ with 3,4 branches. Seta $12-\mathrm{C}$ single or double. Abdomen. Weakly pigmented, light yellowish brown, concolorous with cephalothorax. Usually with more strongly pigmented area on anteromesal portion of terga II-VII. Seta 1-V strong, long, single, extending slightly beyond apex of following segment, similar to $1-\mathrm{V}$. Seta 1-VI strong, long, single, extending beyond apex of following segment. Seta 5-VI similar to 1-VI, strong, long, single, extending beyond apex of following segment. Seta 9-IV-VI spiniform, inserted on caudola-

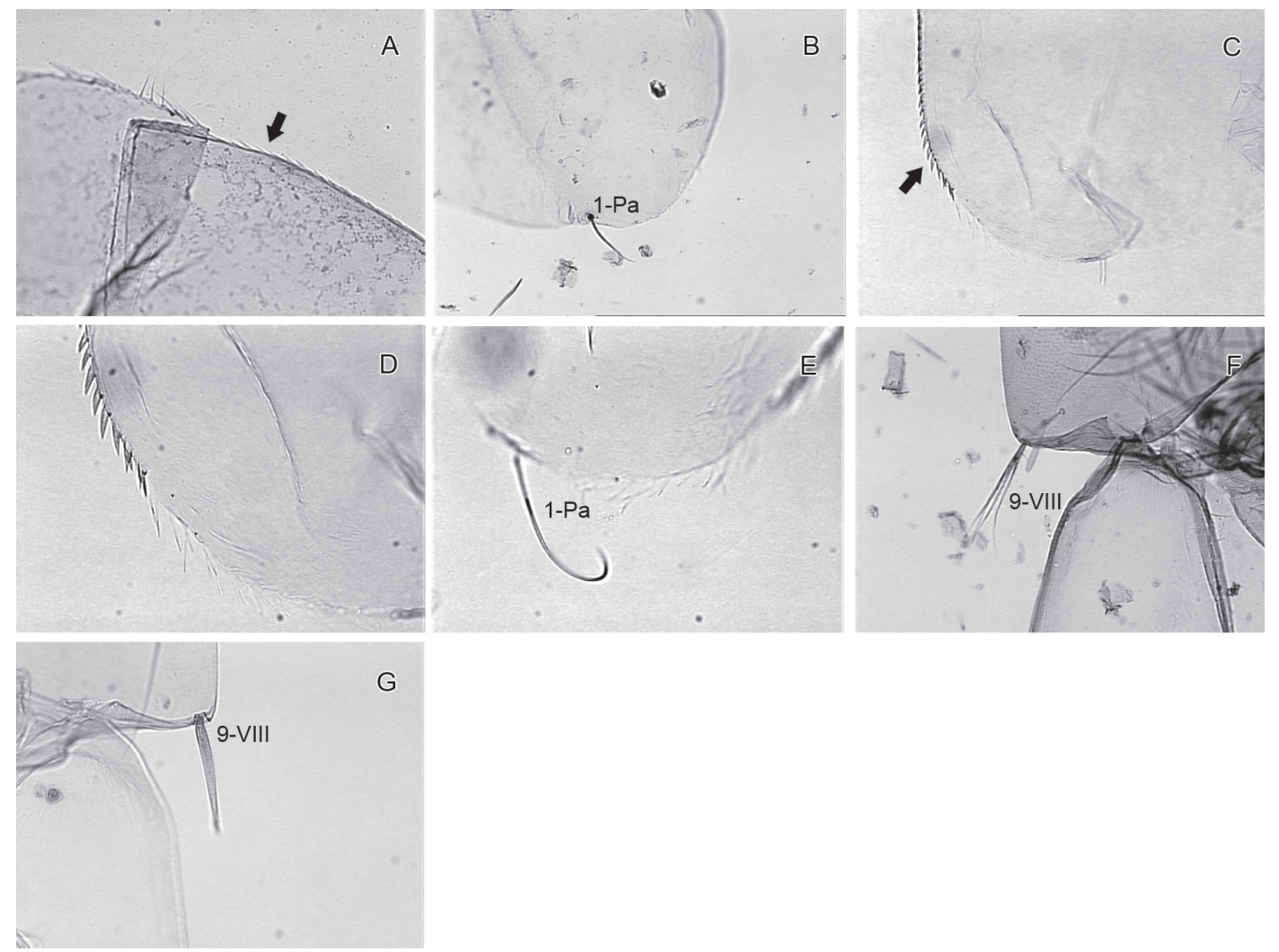

Fig. 4: Anopheles (Nyssorhynchus) pictipennis and Anopheles (Nyssorhynchus) atacamensis, pupa. A: paddle outer basolateral serrations in An. pictipennis; B: seta 1-Pa of An. pictipennis; C, D: paddle outer basolateral serrations in An. atacamensis; E: seta 1-Pa of An. atacamensis; F: seta 9-VIII of An. pictipennis; G: seta 9-VIII of An. atacamensis. 
teral margin of segment, 9-VII, inserted on caudolateral margin of segment, single, 9-VIII spiniform, single, inserted on caudolateral margin of segment (Fig. 4G), seta 9-IV-VIII heavily pigmented, seta 9-V-VIII long, strong, curved. Paddle. Lightly tanned, outer basolateral serrations prominent (Fig. 4C), filamentous spicules on outer margin prominent; seta 1-Pa strong, darkly pigmented, single, curved (Fig. 4E), 2-Pa single or double; toothed margin index 3.8-4.5, paddle teeth well developed (Fig. $4 \mathrm{D})$, teeth broad at base tapering to apex.

DNA sequences - The ITS2 and COI sequences generated during this study are available in GenBank under the following accession numbers: ITS2 (GQ902959GQ902965), COI (F1, GQ902966; F2, GQ902967). Seven clones of the entire ITS2 were sequenced for one individual of An. atacamensis (F1, GQGQ902959-GQ902961) and one individual of An. atacamensis (F2, GQ902962GQ902965). The latter is designated the melanic form because the adult has hindtarsomere 3 dark-scaled on the basal 0.2 , whereas it is entirely white-scaled in F1. The fragment amplified included 119-123 bp of the flanking $5.8 \mathrm{~S}$ gene and $31-32 \mathrm{bp}$ of the $28 \mathrm{~S}$ gene. The cloned sequences were aligned with a single sequence of $A n$. pictipennis from the Atacama Region, Northern Chile (EU433947; Rueda et al. 2008). The length of the ITS2 sequences, excluding the $5.8 \mathrm{~S}$ and $28 \mathrm{~S}$, varied from 426 $432 \mathrm{bp}$ with length variation due to a 6-bp indel (Table II). Two cloned sequences of one individual showed a 6-bp insertion, whereas one cloned sequence of the same individual had a 6-bp deletion. Four cloned sequences of the second individual and EU433947 showed the same 6-bp deletion (Table II). A few base substitutions were observed; however, they were not consistent among the clones. We estimated mean sequence divergence of ITS2 variants within individuals using uncorrected $P$ distance in PAUP (Swofford 2003). Sequence divergence among the clones of An. atacamenis F1 and F2 and EU433947 ranged from 0.00000-0.00769 whereas those of $A n$. atacamensis F1 ranged from 0.00170-0.00520 and An. atacamensis F2 ranged from 0.00172-0.00516. One sequence derived from F1 shares $100 \%$ similarity with a sequence of individual F2. No consistent diagnostic loci were detected for individuals F1 and F2 and EU433947. The nucleotide bases of the ITS2 fragment consist of $22 \%$ A, $19 \% \mathrm{~T}, 27 \% \mathrm{C}$ and $31 \% \mathrm{G}$. A single mtDNA haplotype was detected in the 501-bp COI fragment for both F1 and F2. The nucleotide bases of the COI fragment consist of $30 \% \mathrm{~A}, 38 \% \mathrm{~T}, 17 \% \mathrm{C}$ and $15 \% \mathrm{G}$. Among sequences available in GenBank, the COI gene of An. atacamensis shares the highest similarity ( $92 \%$ in query coverage of 99\%) to that of Anopheles nuneztovari (AF368115), whereas in query coverage of $100 \%$, the highest similarity is shared with Anopheles albitarsis E (DQ076231).

Material examined - Holotype - Pinned adult male with associated genitalia on a microscope slide, bearing the following collection data: Chile, III Región de Atacama, Provincia de Copiapó, Los Perales 30/06/2007 C Reyes Coll, deposited at FSP-USP (E-12984). Paratypes: Chile, III Región de Atacama, Provincia de Copiapó, one male Los Perales, 30/06/2007
C Reyes Coll (FSP-USP, E-12985), one female Totoral 30/06/2007 C Reyes Coll (FSP-USP, E-12994), one male Las Salinas, 02/03/2009 C Reyes Coll (IE-UMCE), one female Las Salinas, 02/03/2009; Provincia de Huasco, one female Quebrada Honda, El Sarco 25/05/2006 C Araya Coll (FSP-USP, E-12995). Three fourth-instar larvae mounted on a separate microscope slides, Provincia de Huasco, Carrizalillo 28/02/2009, C Reyes Coll (FSPUSP E-12986, E-12987, E-12988); three fourth-instar larvae mounted on separate microscope slides, Provincia de Copiapó, Las Salinas 02/03/2009, C Aguilera Coll (FSP-USP, E-12989, E-12990, E-12991).

Other material - Nine specimens of An. pictipennis with the following data: Santiago, Rio Mapocho, A. Neghme Coll., as follow: one pinned adult male with associated male genitalia on microscope slide and two separate slides, one with the right wing and the second with four legs; one male genitalia mounted on microscope slide, not associated with the adult; one pinned adult female; one fourth-instar and one first-instar larva mounted on a separate microscope slides; three pupal exuviae mounted on a single microscope slide; eggs mounted on one microscope slide. Collection 6000-6002; 6126-6128; 6251; 6742-6744. Six fourthinstar larvae from Santiago, location not specified, A. Neghme Coll. 1946, Lane and Neghme Det. 1947. Collection FSP-1 6857-6862. Two females of An. atacamensis for DNA studies (FSP-USP, E-12992, E-12993).

Distribution - An. atacamensis is known from Chile, III Región de Atacama, Provincia de Huasco: Carrizalillo (29 $\left.06^{\circ} \mathrm{S} 71^{\circ} 24^{\prime} \mathrm{W}\right)$, Quebrada Honda El Sarco ( $\left.28^{\circ} 13^{\prime} \mathrm{S} 71^{\circ} 07^{\prime} \mathrm{W}\right)$; Provincia de Copiapó: Perales $\left(27^{\circ} 52^{\prime} \mathrm{S} 70^{\circ} 54^{\prime} \mathrm{W}\right)$, Sector Totoral $\left(27^{\circ} 53^{\prime} \mathrm{S} 70^{\circ} 56^{\prime} \mathrm{W}\right)$, Las Salinas $\left(27^{\circ} 18^{\prime} \mathrm{S} 70^{\circ} 55^{\prime} \mathrm{W}\right)$ and Puerto Viejo $\left(27^{\circ} 19^{\prime} \mathrm{S}\right.$ $70^{\circ} 5^{\prime} \mathrm{W}$ ) (Rueda et al. 2008).

Bionomics (Fig. 5A, B) - Larvae and pupae were found in small, permanent ground pools in oasis areas in the Atacama Desert. The source is ground water that emerges as small fountains in the oasis in Carrizalillo (Provincia de Huasco) (Fig. 5A). The water from the fountains is used to irrigate olive tree plantations, the major crop in the area. The water is clear, fresh, moderately cold (varying from $14-17^{\circ} \mathrm{C}$ ), partially shaded with mud and organic matter on the bottom. Immatures stages were also collected in the Copiapó River (Las Salinas Sector) (Fig. 5B) among Juncaceae vegetation, in a slow current, about $5 \mathrm{~km}$ from the mouth of the river to the Pacific Ocean.

\section{DISCUSSION}

In considering that An. atacamensis is morphologically more similar to An. pictipennis than to any other species of the subgenus Nyssorhynchus, this new species is included in the Pictipennis Subgroup of the Argyritarsis Section of the subgenus. Because of the morphological similarity, specimens of An. atacamensis from the Atacama Región of Northern Chile were misidentified as An. pictipennis by Rueda et al. (2008). However, these species can be distinguished based on characters of the 


\section{TABLE II}

Alignment of the 5.8S, ITS2 and 28S sequences of Anopheles atacamensis from distinct localities in the III Región de Atacama, Northern Chile

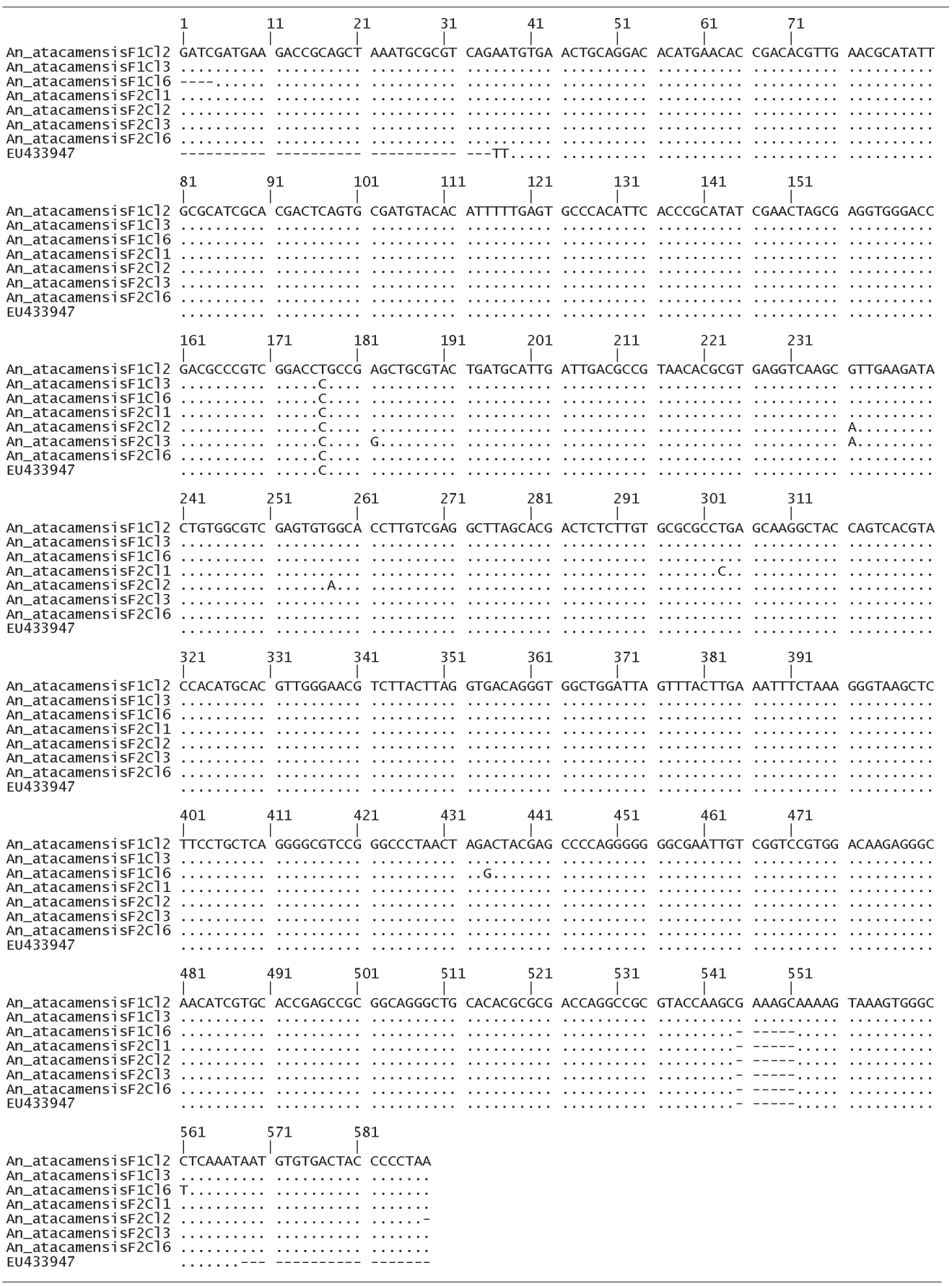

-: either an indel or missing data at the 5' and 3' ends.

male and female adults, male genitalia and fourth-instar larvae. Differential characters of the adult stages of $A n$. atacamensis and An. pictipennis are listed in Table I. Based on the male genitalia, An. atacamensis can be distinguished from An. pictipennis by having the apex of the aedeagus tapered to a blunt point (Fig. 2E), ventromesal subtriangular projection extending ventromedially from the middle length of the aedeagus to form a broad fused arch (Fig. 2D), ventral claspette well projected ventrally, forming two hyaline sacciform, somewhat oval lobes (Fig. 2C) bordering the mesal cleft, basal lobule is elongate, small and narrow and the median sulcus is narrowed at the distal and basal ends and is slightly broader at the middle (Fig. 2B). In An. pictipennis the apex of the 

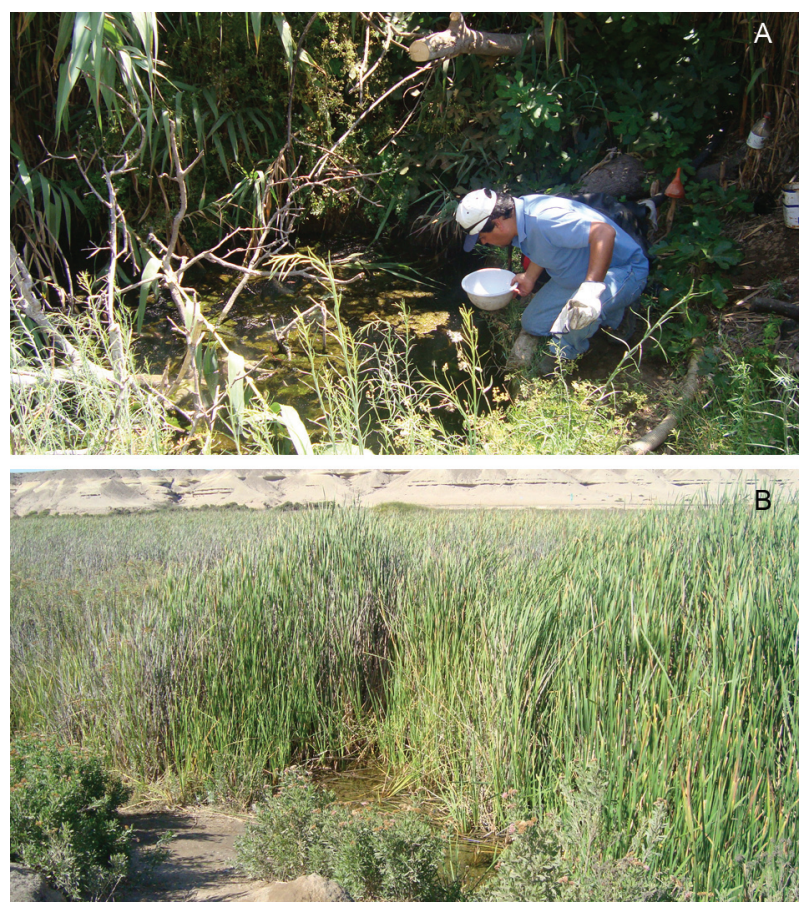

Fig. 5: larval habitat of Anopheles atacamensis. A: Chile, III Región de Atacama, Provincia de Huasco, Carrizalillo; B: Chile, III Región de Atacama, Provincia de Copiapó, Las Salinas.

aedeagus is bluntly rounded, the ventromesal subtriangular projection extends ventromedially to form a narrow, open arch, approximately at mid-length of the aedeagus, the ventral claspette projects weakly ventrally and does not form a distinct sacciform lobe, the basal lobules are poorly developed and the median sulcus is somewhat an inverted U in shape (González \& Sallum 2009). In the fourth-instar larval stage, An. atacamensis can be distinguished from An. pictipennis by having seta 5-C extending well beyond the base of seta $2-\mathrm{C}$, the tubercle of seta 7-C is in line with setae 5,6-C, seta 3-P arises from the same tubercle as 2-P, 10-II, IV are single and 4-X has 8.5 pairs of plumose setae. In An. pictipennis, seta 5-C extends to the base of 2-C, 7-C is inserted anterior to 5,6-C, seta 3-P inserted separately from tubercle of 2-P, seta 10 -II is triple, 10 -IV has four branches and $4-\mathrm{X}$ consists of 10 pairs of plumose setae. In the pupal stage, $A n$. atacamensis can be distinguished from An. pictipennis by having seta 9-VI-VII spiniform and frequently single, 9-VIII is spiniform and always single (Fig. 4G), seta 9-VI has a fine, small branch arising from its mid-length in one of three specimens examined, seta 1-Pa is long and obviously curved (Fig. 4E), the paddle teeth are well developed (Fig. 4D) and the toothed margin index (Sallum et al. 2005) varies from 3.8-4.5 $(\mathrm{n}=2)$. In An. pictipennis, seta 9-VI-VII is spiniform and branched, 9-VIII is spiniform and branched at the apex (Fig. 4F), seta 1-Pa is short and usually straight (Fig. 4B) or curved, the paddle teeth are small and fine (Fig. 4A) and the toothed margin index varies from 1.7-2.0 $(\mathrm{n}=2)$.
The morphological variant found in the Atacama Region may represent a melanic form of An. atacamensis. A similar polymorphism is known in An. albitarsis Lynch Arribálzaga, i.e., An. albitarsis imperfectus Corrêa and Ramos was defined based on the presence of a dark band on hindtarsomere 3 (Corrêa \& Ramos 1943). However, this characteristic was found to be a morphological variation and thus An. imperfectus was synonymized with An. albitarsis by Lane (1953). Wilkerson et al. (1995) proposed that in the subgenus Nyssorhynchus, those individuals with a long dark basal band on hindtarsomere 2 are more likely to have a dark basal band on hindtarsomere 3 . This seems to be the case of the melanic form of An. atacamensis, which has a long dark basal band on hindtarsomere 2 and also a basal dark band on hindtarsomere 3. The COI sequences tell us that these two forms are conspecific because they share a unique haplotype. The ITS2 sequences show singleton polymorphisms and a 6-bp indel among the clones. However, none were consistent and one clone of form F1 and one of F2 share $100 \%$ similarity, suggesting that the variation observed in the ITS2 represents intragenomic variation. It is noteworthy that F1 and F2 were from distinct localities in the Atacama Desert. We expected to find COI variation between these forms, because the populations are isolated in distinct oases in the desert. However, the sample size $(n=2)$ was too small, consequently we cannot draw conclusions about the affinities between these individuals.

Although included in the Argyritarsis Section, An. atacamensis and An. pictipennis share morphological characters with members of the Myzorhynchella Section (Peyton et al. 1992) of the subgenus Nyssorhynchus. Diagnostic characters include the following: in adults, posterolateral scale-tufts are absent from the abdominal segments, in the male genitalia, the ventral claspette lacks spicules on both the ventral and dorsal surfaces, the proctiger is spiculate, the dorsal claspette possesses one subapical and two apical setae, both dorsal and ventral accessory setae end in an acute tip, the aedeagus is strongly developed with serrated lateral leaflets that arise subapically and the ventromesal subtriangular projection extends ventromesally from mid-length of the subapical leaflets, forming a distinct arch; in larvae abdominal seta 6-IV-VII is branched.

The adults of An. atacamensis and An. pictipennis differ from those of the Myzorhynchella Section in having scales on the abdominal terga and the scutum covered with large scales. It is noteworthy that An. pictipennis and An. atacamensis differ from other species of the subgenus Nyssorhynchus by having larval seta 1-II-VII with lanceolate leaflets with notched margins. These species share this type of leaflets with members of the subgenera Anopheles, Lophopodomyia and Stethomyia. Consequently, when using Linthicum's (1988) larval key to identify subgenera of Anopheles, larvae of An. pictipennis and An. atacamensis can be keyed out erroneously to those subgenera.

Edwards (1932) considered Myzorhynchella as a subgenus of Anopheles and An. pictipennis a species of that group. Forattini (1962) adopted Myzorhynchella as 
a subgenus of Anopheles, but An. pictipennis was not assigned to any subgenus. Later, Peyton et al. (1992) defined Myzorhynchella as a section of Nyssorhynchus and retained An. pictipennis in the Argyritarsis Section of Linthicum (1988). Moreover, it is noteworthy that $A n$. pictipennis was not included in the phylogenetic analyses of the Anophelinae conducted by Sallum et al. (2000, 2002), Krzywinski et al. (2001a, b) and Harbach and Kitching (2005). Consequently, the position of the Pictipennis Subgroup within Anopheles is uncertain.

An. pictipennis was collected in the geographically isolated desert zone of Northern Chile, characterized by hyper-aridity that developed progressively with the uplift of the Andes as they reached elevations between 1.000-2.000 m, coupled with the intensification of a cold, upwelling Humboldt Current (Hartley \& Chong 2002 , Houston \& Hartley 2003). The climate of this zone is controlled by its location $\left(15^{\circ}\right.$ and $\left.30^{\circ} \mathrm{S}\right)$ and the Humboldt current (Houston 2006). This isolation suggests an independent evolution of An. pictipennis, in the South, with respect to An. atacamensis, as has apparently occurred with others species in the Atacama Desert (Frías et al. 1998). Probably, An. atacamensis was isolated from other populations by the climatic events that maintain the hyper-aridity of the Atacama Desert. The biota of the Northern Chile is more closely related to Neotropical species than the rest of Chilean insects (Morrone 2006). The southern South American entomofauna is more closely related to taxa of the Australasian Region than to Neotropical taxa (Gondwanan elements) (Morrone 1994, Bourdon et al. 2009, Ribeiro 2009), suggesting that the southern biota may have a composite origin. This could explain the morphological similarity observed among the adults and larvae of An. atacamensis that is shared with species of the Myzorhynchella Section. This section of the subgenus Nyssorhynchus has a geographic distribution that includes regions of Brazil, Bolivia, Peru and Northern Argentina (Galvão 1941, Forattini 1962), but is mainly restricted to Brazil.

\section{ACKNOWLEDGEMENTS}

To Cecilia Luiza Simoes dos Santos, for laboratory assistance in obtaining COI and ITS2 DNA sequences, to Carolina Reyes, Claudio Araya and Carlos Aguilera, for field assistance, and to the anonymous reviewers, for their great contribution to the improvement of the text.

\section{REFERENCES}

Belkin JN 1962. The mosquitoes of the South Pacific (Diptera: Culicidae), 2nd vol., University of California Press, Berkeley and Los Angeles, 608 pp .

Bourdon E, de Ricqles A, Cubos J 2009. A new transantactic relationship: morphological evidence for a Rheidae-Dromaiidae-Casuariidae clade (Aves, Palaeognathae, Ratitae). Zool J Linn Soc 156: 641-663.

Corrêa RR, Ramos AS 1943. Descrição de uma nova sub-espécie de anofelino do sub-gênero Nyssorhynchus Blanchard, 1902 (Diptera: Culicidae). Rev Paul Med 22: 246-248.

Djadid ND, Gholizadeh S, Tafsiri E, Romi R, Gordeev M, Zakeri S 2007. Molecular identification of Palearctic members of Anopheles maculipennis in Northern Iran. Malaria J 17: 6.
Edwards FW 1932. Genera Insectorum. Diptera. Fam. Culicidae. In P Wytsman, Genera Insectorum, Fasc. 194, Desmet-Verteneuil, Bruxelles, $258 \mathrm{pp}$.

Forattini OP 1962. Entomologia médica, vol. 1, Faculdade de Higiene e Saúde Pública, Universidade de São Paulo, São Paulo, 662 pp.

Frías D, Henry AA, González CR 1998. Mepraia gajardoi: a new species of Triatominae (Hemiptera: Reduviidae) from Chile and its comparison with Mepraia spinolai. Rev Chilena Hist Nat 71: 177-188.

Galvão ALA 1941. Contribução ao conhecimento das espécies de Myzorhynchella (Diptera: Culicidae). Arq Zool Sao Paulo 2: 505-576.

González CR, Sallum MAM 2009. Neotype designation and redescription of adult male and immature stages of Anopheles ( $\mathrm{Nys}$ sorhynchus) pictipennis (Phillipi) (Diptera: Culicidae). Zootaxa 2295: 15-24.

Harbach RE, Kitching IJ 2005. Reconsideration of anopheline phylogeny (Diptera: Culicidae: Anophelinae) based on morphological data. Syst Biodiver 3: 345-374.

Harbach RE, Knight KL 1980. Taxonomists' glossary of mosquito anatomy, Plexus Publishing, Marlton, New Jersey, 415 pp.

Hartley AJ, Chong G 2002. Late Pliocene age for the Atacama Desert: implications for the desertification of western South America. Geology 30: 43-46.

Houston J 2006. Variability of precipitation in the Atacama Desert: its causes and hydrological impact. Int J Climatol 26: 2181-2198.

Houston J, Hartley AJ 2003. The central Andean west-slope rainshadow and its potential contribution to the origin of hyper-aridity in the Atacama Desert. Int J Climatol 23: 1453-1464.

Krzywinski J, Wilkerson RC, Besansky N 2001a. Evolution of mitochondrial and ribosomal gene sequences in Anophelinae (Diptera: Culicidae): implications for phylogeny reconstruction. Mol Phylogenet Evol 18: 479-487.

Krzywinski J, Wilkerson RC, Besansky N 2001b. Toward understanding Anophelinae (Diptera: Culicidae) phylogeny: insights from nuclear single copy genes and the weight of evidence. Syst Biol 50: 540-556.

Lane J 1953. Neotropical Culicidae, Universidade de São Paulo, São Paulo, 1112 pp.

Linthicum KJ 1988. A revision of the Argyritarsis Section of the subgenus Nyssorhynchus of Anopheles (Diptera: Culicidae). Mosq Syst 20: 98-271.

Maddison DR, Maddison WP 2000. MacClade 4: analysis of phylogeny and characters evolution, Version 4.0, Sinauer Associates, Sunderland.

Morrone JJ 1994. Distributional patterns of the species of the Rhytirrhinini (Coleoptera: Curculionidae) and the historical relationship of the Andean provinces. Glob Ecol Biogeog Lett 4: 188-194.

Morrone JJ 2006. Biogeographic areas and transition zones of Latin America and the Caribbean Islands based on panbiogeographic and cladistic analysis of the entomofauna. Annu Rev Entomol 51: 467-494.

Peyton EL, Wilkerson RC, Harbach RE 1992. Comparative analysis of the subgenera Kerteszia and Nyssorhynchus of Anopheles (Diptera: Culicidae). Mosq Syst 24: 51-69.

Ribeiro GC 2009. The Neotropical genus Stibadocerina Alexander and its phylogenetic relationship to other Stibadocerinae genera: further evidence of an ancestral trans-Pacific biota. Syst Entomol 34: $324-333$. 
Rueda LM, Rodriguez JA, Betugio MC, Pecor JE, Li C, Wilkerson RC 2008. Anopheles (Nyssorhynchus) pictipennis (Philippi): a new mosquito record from the Atacama Region of Northern Chile. J Am Mosq Control Assoc 24: 448-449.

Sallum MAM, Peyton EL, Harrison BA, Wilkerson RC 2005. Revision of the Leucosphyrus Group of Anopheles (Cellia) (Diptera: Culicidae). Rev Bras Entomol 49: 1-152.

Sallum MAM, Schultz TR, Foster PG, Aronstein K, Wirtz RA, Wilkerson RC 2002. Phylogeny of Anophelinae (Diptera: Culicidae) based on nuclear ribosomal and mitochondrial DNA sequences. Syst Entomol 27: 361-382.

Sallum MAM, Schultz TR, Wilkerson RC 2000. Phylogeny of Anophelinae (Diptera: Culicidae) based on morphological characters. Ann Entomol Soc Am 93: 745-775.
Simon FF, Beckenbach A, Crespi B, Liu H, Flook P 1994. Evolution, weighting and phylogenetic utility of mitochondrial gene sequences and a compilation of conserved polymerase chain reaction primers. Ann Entomol Soc Am 87: 651-701.

Swofford DL 2003. PAUP*. Phylogenetic Analysis Using Parsimony (*and Other Methods). Version 4. Sinauer Associates, Sunderland, Massachusetts.

Wilkerson RC, Hribar LJ, Milstrey EG, Falero GC 1995. The identification of Anopheles (Nyssorhynchus) rondoni (Diptera: Culicidae) in Mato Grosso state, Brazil: an analysis of key character variability. Mem Inst Oswaldo Cruz 90: 575-582.

Wilkerson RC, Peyton EL 1990. Standardized nomenclature for the costal wing spots of the genus Anopheles and other spotted-winged mosquitoes (Diptera: Culicidae). J Med Entomol 27: 207-224. 